\title{
Pengembangan Sensor Kesegaran Edible untuk Fillet lkan Tuna (Thunnus albacares) Berbasis Antosianin Kulit Buah Juwet (Syzygium cumini) dengan Membran Selulosa Bakterial
}

\section{(The Development of Edible Freshness Sensor for Fillet Tuna Fish (Thunnus albacares) Based on Antosianin Juwet (Syzygium cumini) with Bacterial Cellulose Membrane)}

\author{
Lilis Amongsari, Bambang Kuswandi, Nia Kristiningrum \\ Fakultas Farmasi Universitas Jember Jln. Kalimantan 37, Jember 68121 \\ e-mail korespondensi: b.kuswandi@gmail.com; lilisamong@gmail.com
}

\begin{abstract}
Fishery products are the foodstuffs that are popular with many people. One of the processed fisheries products that people like is tuna fillets. This product required quality of tuna fillet, so the analytical tool was needed to analyze the freshness of tuna fillets easily and practically. The purpose of this study was to develop an edible freshness sensor based on anthocyanin juwet (Syzygium cumini) with bacterial cellulose membrane from nata de coco. The edible freshness sensor can be applied as a freshness sensor for determine of the freshness level of tuna fish fillets with various parameters. Tested for the freshness of tuna fillets were included total microbial test, total volatile bases nitrogen (TVB-N) test, $p H$ value, texture value, and organoleptic test. The color change of an edible freshness sensor was observed visually and tested using the imageJ program to determine the value of mean green. The results showed that a change in the color of freshness sensor namely dark purple when tuna fillets were fresh, light purple when tuna fillets were still fresh and gray when tuna fillets were no longer fresh. The value of mean green from edible freshness sensor increase with decreasing the freshness level of tuna fillets.
\end{abstract}

Keywords: Anthocyanin, freshness sensor, nata de coco, tuna

\begin{abstract}
Abstrak
Produk perikanan merupakan bahan pangan yang banyak digemari oleh masyarakat. Salah satu hasil pengolahan produk perikanan yang disukai masyarakat adalah fillet ikan tuna. Hal tersebut diikuti dengan tuntutan kualitas mutu produk fillet ikan tuna, sehingga dibutuhkan suatu alat analisa yang dapat menganalisis kesegaran fillet ikan tuna secara mudah dan praktis. Penelitian ini bertujuan untuk mengembangkan sensor kesegaran edible berbasis indikator antosianin dari ekstrak kulit buah juwet (Syzygium cumini) dengan membran selulosa bakterial dari nata de coco. Sensor kesegaran edible tersebut dapat diaplikasikan sebagai sensor kesegaran dan mengetahui tingkat kesegaran fillet ikan tuna dengan berbagai parameter. Dilakukan uji parameter kesegaran fillet ikan tuna meliputi uji total mikroba, uji total volatile bases nitrogen $(T V B-N)$, nilai $\mathrm{pH}$, nilai tekstur, dan uji organoleptis. Perubahan warna sensor kesegaran edible diamati secara visual dan diuji menggunakan program ImageJ untuk menentukan nilai mean green. Hasil menunjukkan perubahan warna sensor kesegaran yaitu ungu tua saat fillet ikan tuna dalam keadaan segar, ungu muda saat fillet ikan tuna masih segar dan abu-abu ketika fillet ikan tuna sudah tidak lagi segar. Nilai mean green sensor kesegaran edible meningkat seiring dengan penurunan tingkat kesegaran fillet ikan tuna.
\end{abstract}

Kata Kunci: Antosianin, nata de coco, sensor kesegaran, tuna

\section{Pendahuluan}

Produk perikanan merupakan salah satu bahan pangan yang digemari oleh masyarakat. Fillet ikan tuna merupakan hasil pengolahan produk perikanan yang sering dijumpai di pasaran. Seperti produk perikanan lainnya fillet ikan rentan mengalami kerusakan dan memiliki masa simpan yang pendek [1]. Saat ini penilaian penurunan mutu ikan masih menggunakan cara-cara sensori, seperti melihat penampilan dan warna ikan, mencium aroma ikan, meraba tekstur ikan. Ikan yang rusak akibat mikroorganisme akan memproduksi senyawasenyawa basa nitrogen yang mudah menguap atau 
disebut juga total volatile bases nitrogen (TVB- $N$. Senyawa tersebut dapat digunakan untuk mengetahui kesegaran ikan [2]. Peningkatan konsentrasi TVB- $N$ mengakibatkan peningkatan $\mathrm{pH}$ pada ikan [3].

Peningkatan $\mathrm{pH}$ pada ikan dapat dimanfaatkan untuk mendeteksi kesegaran ikan. Beberapa tahun terakhir telah banyak dilakukan beberapa penelitian yang memanfaatkan indikator kolorimetri untuk evaluasi kesegaran ikan dengan memanfaatkan perubahan $\mathrm{pH}$ pada ikan. Huang, dkk. [4] yang mengevaluasi kesegaran ikan menggunakan bromcresol purple, green dan cresol red. Demikian pula Kuswandi, dkk. [5], yang mengevaluasi indikator kolorimetri berbasis polyaniline untuk mendeteksi kebusukan pada ikan. Namun, penggunaan senyawa-senyawa kimia tersebut mulai dihindari karena memiliki potensi efek berbahaya bagi manusia yang bersifat karsinogenik atau mutagenik $[6,7]$. Pigmen pewarna alami dapat digunakan sebagai alternatif indikator kolorimetri yang dinilai lebih aman, tidak toksik, mudah dipreparasi, dan ekonomis jika dibandingkan dengan pewarna kemosintesis $[7,8]$.

Antosianin merupakan pigmen alami yang memiliki rentang respon yang luas terhadap variasi $\mathrm{pH}$ [9]. Buah yang mengandung antosianin adalah Juwet atau Syzygium cumini banyak ditemukan di Indonesia. Juwet memiliki kandungan antosianin yang tinggi pada kulit buahnya [10]. Warna antosianin yang diekstraksi dari kulit buah Juwet matang pada $\mathrm{pH}$ rendah berwarna merah dan berwarna hijau sampai kuning pada $\mathrm{pH}$ tinggi, sehingga berpotensi sebagai indikator kolorimetri dalam pembuatan sensor. Penggunaan indikator kolorimetri membutuhkan membran sebagai media reaksi antara reagen dan analit pada suatu pembuatan sensor. Penggunaan selulosa bakterial sebagai membran edible dapat menjadi pilihan karena terbuat dari bahan alami, ramah lingkungan dan aman jika dikonsumsi [11].

Penelitian ini bertujuan untuk mengetahui apakah sensor kesegaran edible dapat diaplikasikan sebagai indikator kesegaran fillet ikan tuna, dilakukan berbagai uji parameter tingkat kesegaran fillet ikan tuna, serta hubungan antara perubahan warna sensor tersebut dengan berbagai parameter tingkat kesegaran fillet ikan tuna. Hasil dari penelitian ini diharapkan mampu memberi informasi tentang tingkat kesegaran fillet ikan tuna kepada konsumen tanpa membuka kemasan.

\section{Metode Penelitian}

\section{Alat dan Bahan}

Alat yang digunakan pada penelitian ini meliputi pisau, blender, timbangan analitik, gelas ukur $25 \mathrm{~mL}$, vial, pipet tetes, ball pipet, plat tetes, pinset, batang pengaduk, labu ukur $5 \mathrm{~mL}$, kuvet, spektrofotometri UV-vis, autoklaf, incubator, rheotex, petry disk, oven, termometer, $\mathrm{pH}$ meter, refrigerator, Laminar air flow,

e-Journal Pustaka Kesehatan, vol. 8 (no.2), Mei 2020 bluetip, yellowtip, press kaca, scanner, dan software ImageJ.

Bahan yang digunakan dalam penelitian ini adalah fillet ikan tuna (Thunnus albacares) yang dibeli di Hypermart Jember, kulit buah juwet (Syzygium cumini) yang diambil dari desa Parang, kecamatan Parang, Magetan, nata de coco tanpa pemanis yang dibeli di pasar tradisional "Tanjung" Jember, aquades, etanol 96\%, Polivinil Alkohol (PVA), media plate count agar (PCA), kalium klorida $(\mathrm{KCl})$, natrium asetat $\left(\mathrm{CH}_{3} \mathrm{CO}_{2} \cdot 3 \mathrm{H}_{2} \mathrm{O}\right)$.

\section{Pembuatan Ekstrak Kulit Buah Juwet}

Indikator kulit buah juwet diawali dengan menyiapkan simplisia kulit buah juwet. Ekstraksi dilakukan dengan menimbang 2 gram kulit buah juwet kering yang dimaserasi dengan $10 \mathrm{~mL}$ etanol $96 \%$ selama 60 menit, kemudian diremaserasi dengan cara yang sama sehingga diperoleh ekstrak dengan konsentrasi $10 \% \mathrm{~b} / \mathrm{v}$. Ekstrak kulit buah juwet yang digunakan ditentukan kadar antosianin totalnya. Penentuan kadar antosianin total dilakukan dengan metode perbedaan $\mathrm{pH}$ ( $\mathrm{pH}$ differential).

\section{Pembuatan Membran Selulosa Bakterial}

Membran selulosa bakterial dibuat dengan mengancurkan 114 gram nata de coco hingga membentuk bubur dan dihilangkan sisa airnya. Bubur dituangkan pada press kaca berukuran $5 \mathrm{~cm} \times 15 \mathrm{~cm}$ dengan ketebalan $3 \mathrm{~mm}$. Bubur nata de coco yang telah di press dimasukkan dalam oven dengan suhu $100{ }^{\circ} \mathrm{C}$ selama 18 jam agar dihasilkan membran kering.

\section{Fabrikasi Sensor Kesegaran Edible}

Fabrikasi sensor kesegaran edible dilakukan menggunakan membran selulosa bakterial yang dipotong berbentuk lingkaran dengan diameter $7 \mathrm{~mm}$. Pengimobilisasian dilakukan menggunakan teknik adsorpsi pada ekstrak kulit buah juwet yang telah diimobilisasi dengan teknik entrapment pada PVA $0,1 \%$ dengan perbandingan ekstrak dan PVA $1: 3$ selama 90 menit.

\section{Label Pintar Sebagai Sensor Kesegaran Edible}

Desain label dibuat seperti pada gambar 1 . Label yang disertai freshness sign diletakkan pada bagian dalam kemasan fillet ikan tuna untuk mengetahui tingkat kesegarannya.

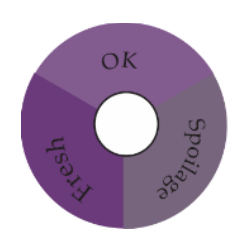

Gambar 1. Desain label sensor kesegaran

\section{Analisis Perubahan Warna Sensor Kesegaran Edible}


Pengamatan perubahan warna sensor kesegaran edible dilakukan secara visual dan menggunakan software ImageJ untuk mengetahui nilai mean green. Pengambilan gambar dilakukan menggunakan scanner.

\section{Uji Total Mikroba}

Alat yang digunakan untuk analisis total mikroba harus dalam kondisi steril. $1 \mathrm{~g}$ sampel dihancurkan dan dimasukkan dalam tabung reaksi yang berisi $9 \mathrm{~mL}$ aquades steril, kemudian dihomogenkan menggunakan vortex sehingga diperoleh pengenceran $10^{-1}$. Dari larutan induk tersebut diambil $1 \mathrm{~mL}$ kemudian dimasukkan dalam tabung reaksi yang berisi $9 \mathrm{~mL}$ aquades steril kemudian dihomogenkan menggunakan vortex sehingga diperoleh pengenceran $10^{-2}$, demikian sterusnya sampai diperoleh pengenceran $10^{-4}$. $1 \mathrm{~mL}$ suspensi dari setiap pengenceran diinokulasikan ke dalam cawan petri dan dituangi $10 \mathrm{~mL}$ plate count agar (PCA) yang masih cair namun telah didinginkan. Goyangkan sampai merata dan biarkan memadat. Cawan diinkubasi pada suhu $37^{\circ} \mathrm{C}$ selama 48 jam. Hasil pertumbuhan koloni pada media agar dihitung dengan menggunakan Coloni Counter [12]. Jumlah koloni dapat dihitung dengan persamaan:

Koloni per $\mathrm{mL}=$ Jumlah koloni percawan $\times 1 /$ (Faktor Pengenceran $)$

\section{Uji Total Volatile Bases Nitrogen (TVB-M)}

Total Volatile Base pada fillet ikan tuna dihitung dengan menggunkan destilasi Kjeldahl. Sebanyak 10 g sampel dihaluskan, dan dimasukkan dalam beaker glass yang berisi $100 \mathrm{~mL}$ aquades. Sampel didiamkan selama 30 menit dengan pengadukan setiap 10 menit, kemudian larutan disaring dengan kertas saring. $5 \mathrm{~mL}$ filtrat dibasakan dengan menambahkan $5 \mathrm{ml} \mathrm{MgO} 10 \mathrm{~g} / \mathrm{L}$. Larutan kemudian didestilasi menggunakan destilasi Kjeldahl selama 5 menit. Destilat diabsorbsi dengan $10 \mathrm{~mL}$ asam borat $20 \mathrm{~g} / \mathrm{L}$ yang telah ditambahkan 5-6 tetes indikator metil merah metil biru (MMMB) dan dititrasi dengan HCL $0,01 \mathrm{~N}$ hingga terjadi perubahan warna biru keunguan [13]. TVB-N d apat ditentukan dengan persamaan sebagai berikut :

$$
\operatorname{TVB}-N(\mathrm{mg} / 100 \mathrm{~g})=\times 100
$$

\section{Uji Nilai pH}

Sebanyak $1 \mathrm{~g}$ sampel dihancurkan dan dilarutkan dalam $20 \mathrm{~mL}$ aquadest dan dihomogenkan. Tingkat keasaman diukur dengan $\mathrm{pH}$ meter yang sebelumnya telah dikalibrasi dengan buffer standar 4, 7, dan 10 [14].

\section{Uji Tekstur}

Tekstur fillet ikan tuna diukur dengan menggunakan Rheotex. Pengukuran dilakukan dengan menusukkan jarum rheotex sedalam $10 \mathrm{~mm}$ pada fillet ikan tuna dengan ketebalan $\pm 3 \mathrm{~cm}$. Angka yang ditunjukkan jarum rheotex (g) merupakan nilai tekstur dari ikan. Pengukuran dilakukan di 10 titik pada setiap sampel [15].

\section{Uji Organoleptis}

Pada uji ini dilakukan penilaian pada kenampakan warna dan bau. 10 orang panelis akan memberikan nilai pada sampel yang diamati. Semakin segar ikan nilainya akan semakin tinggi. Nilai yang diberikan berkisar 9-1. Penilaian dilakukan berdasarkan scoresheet SNI 2346:2011 [16].

\section{Hasil}

\section{Pembuatan Ekstrak Kulit Buah Juwet}

Berdasarkan hasil penelitian ini diperoleh ratarata konsentrasi antosianin total ekuivalen sianidin-3glikosida dari ekstrak kulit buah juwet yang digunakan sebesar $2.621,725 \pm 11,665 \mathrm{mg} / \mathrm{L}$.

\section{Pembuatan Membran Selulosa Bakterial}

Membran kering yang dihasilkan memiliki ketebalan 0,20 mm, kemudian dipotong dengan diameter $7 \mathrm{~mm}$. Membran selulosa bakterial yang siap dipakai dapat dilihat pada gambar 2 .

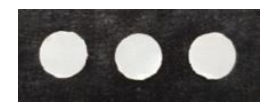

Gambar 2. Membran selulosa bakterial

\section{Fabrikasi Sensor Kesegaran Edible}

Fabrikasi dilakukan dengan melakukan imobilisasi ekstrak kulit buah juwet pada membran selulosa bakterial. Hasil fabrikasi dapat dilihat pada gambar 3.

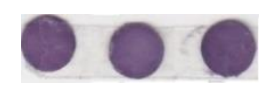

Gambar 3. Membran selulosa bakterial yang telah diimobilisasi

\section{Perubahan Warna Sensor Kesegaran Edible}

\begin{tabular}{lllllllllllll}
\hline $\begin{array}{l}\text { Waktu } \\
\text { (jam) }\end{array}$ & 2 & 4 & 6 & 8 & 10 & 12 & 14 & 16 & 18 & 20 & 22 & 24 \\
\hline Warna & 8 & 0 & & & & & & & & & &
\end{tabular}

Gambar 5. Perubahan warna sensor kesegaran edible pada penyimpanan suhu ruang

Sensor kesegaran edible pada fillet ikan yang disimpan pada suhu ruang dapat diamati perubahan warna secara visual pada gambar 5. Membran kemudian discan dan dianalisis menggunakan software ImageJ. Pada tabel 1 dapat dilihat adanya peningkatan nilai mean green seiring lamanya waktu penyimpanan. 
Tabel 1. Nilai mean green penyimpanan suhu ruang

\begin{tabular}{cc}
\hline Jam & Mean green \pm SD \\
\hline 2 & $78,207 \pm 1,308$ \\
4 & $86,179 \pm 1,800$ \\
6 & $100,335 \pm 4,116$ \\
8 & $106,407 \pm 2,846$ \\
10 & $109,239 \pm 4,709$ \\
12 & $116,607 \pm 1,421$ \\
14 & $120,345 \pm 3,837$ \\
16 & $124,431 \pm 2,809$ \\
18 & $126,370 \pm 1,194$ \\
20 & $128,253 \pm 3,953$ \\
22 & $131,779 \pm 3,005$ \\
24 & $134,037 \pm 1,255$ \\
\hline
\end{tabular}

\section{Uji Total Mikroba}

Uji total mikroba pada fillet ikan tuna yang disimpan pada suhu ruang selama 24 jam dihitung menggunakan metode total plate count (TPC). Hasil uji total mikroba dapat dilihat pada tabel 2 .

Tabel 2. Hasil uji total mikroba

\begin{tabular}{ccc}
\hline Jam & $\mathrm{cfu} / \mathrm{g}$ & $\log \mathrm{cfu} / \mathrm{g}$ \\
\hline 2 & $4,3 \times 10^{3}$ & 3,633 \\
4 & $1,8 \times 10^{4}$ & 4,255 \\
6 & $2,5 \times 10^{4}$ & 4,398 \\
8 & $4,7 \times 10^{4}$ & 4,672 \\
10 & $3,1 \times 10^{5}$ & 5,491 \\
12 & $3,7 \times 10^{5}$ & 5,568 \\
14 & $2,7 \times 10^{6}$ & 6,431 \\
16 & $4,6 \times 10^{6}$ & 6,663 \\
18 & $2,8 \times 10^{7}$ & 7,447 \\
20 & $4,2 \times 10^{7}$ & 7,623 \\
22 & $2,4 \times 10^{8}$ & 8,380 \\
24 & $3,5 \times 10^{8}$ & 8,544 \\
\hline
\end{tabular}

\section{Uji Total Volatile Bases Nitrogen (TVB-M)}

Fillet ikan tuna yang disimpan pada suhu ruang selama 24 ditentukan nilai $T V B-N$, yang dapat dilihat pada tabel 3.

Tabel 3. Hasil uji TVB-N

\begin{tabular}{cc}
\hline Jam & $T V B-N(\mathrm{mg} / 100 \mathrm{~g}) \pm \mathrm{SD}$ \\
\hline 2 & $6,907 \pm 0,323$ \\
4 & $10,640 \pm 0,000$ \\
6 & $16,987 \pm 0,323$ \\
8 & $20,907 \pm 0,428$ \\
10 & $24,453 \pm 0,323$ \\
12 & $28,747 \pm 0,647$ \\
14 & $34,160 \pm 0,970$ \\
16 & $36,220 \pm 0,312$ \\
18 & $41,067 \pm 0,323$ \\
20 & $45,733 \pm 0,323$ \\
22 & $55,627 \pm 0,647$ \\
24 & $59,920 \pm 0,970$ \\
\hline
\end{tabular}

\section{Uji Nilai pH}

Nilai $\mathrm{pH}$ fillet ikan tuna ditentukan menggunakan $\mathrm{pH}$ meter. Hasil pengamatan $\mathrm{pH}$ dapat dilihat pada tabel 4.

\begin{tabular}{|c|c|}
\hline Jam & Nilai $\mathrm{pH} \pm \mathrm{SD}$ \\
\hline 2 & $5,60 \pm 0,015$ \\
\hline 4 & $5,55 \pm 0,104$ \\
\hline 6 & $5,64 \pm 0,012$ \\
\hline 8 & $5,75 \pm 0,006$ \\
\hline 10 & $5,87 \pm 0,012$ \\
\hline 12 & $6,15 \pm 0,012$ \\
\hline 14 & $6,20 \pm 0,006$ \\
\hline 16 & $6,33 \pm 0,006$ \\
\hline 18 & $6,45 \pm 0,006$ \\
\hline 20 & $6,52 \pm 0,006$ \\
\hline 22 & $6,53 \pm 0,030$ \\
\hline 24 & $6,75 \pm 0,392$ \\
\hline
\end{tabular}

\section{Uji Tekstur}

Uji tekstur dilakukan menggunakan alat Rheotex dengan kedalaman jarum $10 \mathrm{~mm}$. Hasil uji tekstur dapat dilihat pada tabel 5 .

Tabel 5. Hasil uji tekstur

\begin{tabular}{cc}
\hline Jam & Mean $\pm \mathrm{SD}(\mathrm{g} / 10 \mathrm{~mm})$ \\
\hline 2 & $277,4 \pm 30,526$ \\
4 & $249,5 \pm 15,750$ \\
6 & $221,2 \pm 16,825$ \\
8 & $201,1 \pm 29,316$ \\
10 & $172,1 \pm 17,130$ \\
12 & $152,7 \pm 18,518$ \\
14 & $137,5 \pm 17,116$ \\
16 & $129,2 \pm 8,929$ \\
18 & $116,7 \pm 9,250$ \\
20 & $108,9 \pm 12,931$ \\
22 & $87,2 \pm 9,151$ \\
24 & $69,3 \pm 15,671$ \\
\hline
\end{tabular}

\section{Uji Organoleptis}

Uji organoleptik fillet ikan tuna yang disimpan pada suhu ruang dilakukan dengan menyertakan 10 orang panelis menggunakan score sheet penilaian udang segar berdasarkan SNI 2346:2011. Pada penelitian ini hanya dilakukan pengamatan organoleptis warna dan bau. Hasil uji organoleptik dapat dilihat pada Tabel 6.

Tabel 6. Hasil uji organoleptis

\begin{tabular}{ccc}
\hline Jam & Organoleptis bau \pm SD & Organoleptis warna $\pm S D$ \\
\hline 2 & $9,000 \pm 0,000$ & $9,000 \pm 0,000$ \\
4 & $9,000 \pm 0,000$ & $9,000 \pm 0,000$ \\
6 & $8,267 \pm 0,306$ & $7,600 \pm 0,000$ \\
8 & $7,533 \pm 0,115$ & $7,067 \pm 0,115$ \\
10 & $7,200 \pm 0,000$ & $7,000 \pm 0,000$ \\
12 & $7,000 \pm 0,000$ & $7,000 \pm 0,000$ \\
14 & $5,133 \pm 0,115$ & $5,067 \pm 0,231$ \\
16 & $4,000 \pm 0,000$ & $4,533 \pm 0,115$ \\
18 & $3,000 \pm 0,000$ & $3,133 \pm 0,115$ \\
20 & $2,067 \pm 0,115$ & $3,000 \pm 0,000$ \\
22 & $1,467 \pm 0,231$ & $3,000 \pm 0,000$ \\
24 & $1,000 \pm 0,000$ & $3,000 \pm 0,000$ \\
\hline
\end{tabular}

\section{Pembahasan}

Seiring lamanya waktu penyimpanan fillet ikan tuna mengalami penurunan mutu baik secara mikrobiologi, kimiawi, fisikawi maupun organoleptis. Berdasarkan hasil pengamatan warna sensor 
kesegaran edible pada kemasan fillet ikan tuna pada penyimpanan suhu ruang, warna sensor kesegaran edible mengalami perubahan seiring dengan perubahan tingkat kesegaran fillet ikan tuna seperti yang ditunjukan pada gambar 5. Warna sensor kesegaran edible berwarna ungu tua pada saat fillet ikan tuna segar, berwarna ungu muda saat masih segar, dan berwarna abu-abu saat sudah busuk atau tidak dapat dikonsumsi.

Jumlah mikroba sebagai parameter mikrobiologi menjadi faktor penting dalam penentuan kualitas pangan [17]. Menurut SNI 01-27279.1-2006 batas maksimal total mikroba pada ikan dapat dikonsumsi yaitu berjumlah $5 \times 10^{5} \mathrm{cfu} / \mathrm{g}$ atau nilai log TPC 5,70 cfu/g [18]. Jumlah mikroba pada fillet ikan yang disimpan pada suhu ruang mengalami peningkatan seiring lamanya waktu penyimpanan. Peningkatan jumlah mikroba akan menghasilkan senyawasenyawa basa nitrogen yang mudah menguap atau disebut juga total volatile bases nitrogen (TVB- $N$ ) yang sebagian besar terdiri dari trimetilamin (TMA), dimetilamin (DMA), dan amonia. Senyawa tersebut dapat digunakan untuk mengetahui kesegaran ikan, batas maksimum TVB-N pada ikan yang dapat dikonsumsi adalah $30 \mathrm{mg} / 100 \mathrm{~g}$ [2]. Peningkatan konsentrasi TVB-N mengakibatkan peningkatan $\mathrm{pH}$ pada ikan dan suasana disekitar sensor menjadi basa, sehingga terjadi perubahan warna sensor kesegaran edible [3].

Nilai tekstur fillet ikan tuna mengalami penurunan selama penyimpanan pada suhu ruang. Penurunan nilai tekstur menandakan adanya penurunan mutu ikan. Saat ikan mengalami penurunan mutu, daging ikan akan melunak akibat terjadinya perombakan pada jaringan otot daging oleh aktivitas enzim dalam hidrolisis protein [19]. Selain itu, Hasil penilaian organoleptis bau dan kenampakan warna daging ikan yang disimpan pada suhu ruang mengalami penurunan seiring lamanya waktu penyimpanan.

Hasil penilaian parameter mikrobiologi, kimiawi, fisikawi, dan organoleptis menunjukkan fillet ikan tuna busuk atau tidak layak dikonsumsi saat jam ke-14 pada penyimpanan suhu ruang. Pada jam ke-14 fillet ikan tuna tidak dapat dikonsumsi dikarenakan jumlah mikroba telah melebihi batas maksimum yaitu $2,7 \mathrm{x}$ $10^{6} \mathrm{cfu} / \mathrm{g}$ atau $6,431 \mathrm{log} \mathrm{cfu} / \mathrm{g}$, TVB-N juga melebihi batas maksimum yaitu $34,160 \pm 0,970 \mathrm{mg} / 100 \mathrm{~g}$ dengan nilai $\mathrm{pH} 6,20 \pm 0,006$. Selain itu, nilai tekstur pada jam ke-14 mengalami penurunan hingga 137,5 $\pm 17,116 \mathrm{~g} / 10 \mathrm{~mm}$, serta hasil pengamatan organoleptis bau dan warna memiliki nilai kurang dari 7 yang menandakan fillet ikan tuna sudah tidak layak dikonsumsi.

Berdasarkan hasil penilaian parameter mikrobiologi, kimiawi, fisikawi, dan organoleptis menunjukkan adanya hubungan dengan perubahan warna serta nilai mean green sensor kesegaran edible. Saat fillet ikan tuna sudah tidak dapat dikonsumsi, warna sensor kesegaran edible akan berwarna abu-abu dan terjadi peningkatan nilai mean green.

e-Journal Pustaka Kesehatan, vol. 8 (no.2), Mei 2020

\section{Simpulan dan Saran}

Sensor kesegaran edible berbasis antosianin kulit buah juwet (Syzygium cumini) dengan membran selulosa bakterial nata de coco dapat diaplikasikan pada kemasan fillet ikan tuna sebagai indikator kesegaran. Sensor kesegaran edible berwarna ungu tua pada saat fillet ikan tuna segar, berwarna ungu muda saat masih segar, dan berwarna abu-abu saat sudah busuk atau tidak dapat dikonsumsi [4].

Hubungan antara perubahan warna sensor kesegaran edible dan nilai mean green dengan penurunan mutu fillet ikan tuna adalah berbanding terbalik. Nilai mean green sensor kesegaran edible yang diamati menggunakan program ImageJ meningkat seiring penurunan mutu fillet ikan tuna.

\section{Daftar Pustaka}

[1] A. Pacquit, K. Crowley, and D. Diamond, "Smart packaging technologies for fish and seafood products," Smart Packag. Technol. Fast Mov. Consum. Goods, pp. 75-98, 2008.

[2] S. Bhadra, C. Narvaez, D. J. Thomson, and G. E. Bridges, "Non-destructive detection of fish spoilage using a wireless basic volatile sensor," Talanta, vol. 134, pp. 718-723, 2015.

[3] A. Pacquit et al., "Development of a smart packaging for the monitoring of fish spoilage," Food Chem., vol. 102, no. 2, pp. 466-470, 2007.

[4] X. Huang, J. Xin, and J. Zhao, "A novel technique for rapid evaluation of fish freshness using colorimetric sensor array," J. Food Eng., vol. 105, no. 4, pp. 632-637, 2011.

[5] B. Kuswandi, Jayus, A. Restyana, A. Abdullah, L. Y. Heng, and M. Ahmad, "A novel colorimetric food package label for fish spoilage based on polyaniline film," Food Control, vol. 25, no. 1, pp. 18-189, 2012.

[6] S. Srivastava, R. Sinha, and D. Roy, "Toxicological effects of malachite green," Aquat. Toxicol., vol. 66, no. 3, pp. 319-329, 2004.

[7] X. Zhang, S. Lu, and X. Chen, "A visual $\mathrm{pH}$ sensing film using natural dyes from Bauhinia blakeana Dunn," Sensors Actuators, B Chem., vol. 198, pp. 268-273, 2014.

[8] I. Choi, J. Y. Lee, M. Lacroix, and J. Han, "Intelligent $\mathrm{pH}$ indicator film composed of agar/potato starch and anthocyanin extracts from purple sweet potato," Food Chem., vol. 218, pp. 122-128, 2017.

[9] X. Zhai et al., "Novel colorimetric films based on starch/polyvinyl alcohol incorporated with roselle anthocyanins for fish freshness monitoring," Food Hydrocoll., vol. 69, pp. 308-317, 2017.

[10] P. Sari, C. H. Wijaya, D. Sajuthi, and U. Supratman, "Colour properties, stability, and free radical scavenging activity of jambolan (Syzygium cumini) fruit anthocyanins in a beverage model system: Natural and 
Amongsari, et al., Pengembangan Sensor Kesegaran Edible untuk....

copigmented anthocyanins," Food Chem., vol. 132, no. 4, pp. 1908-1914, 2012.

[11] M. Zulfajri and Muttakin, "Metode ekstraksi antosianin dari kulit buah Syzygium cumini (L.) skeels sebagai indikator alami asam basa," in Seminar Nasional II USM, 2017, vol. 1, pp. 547553.

[12] K. T. P. Sari, Pemanfaatan Tepung Biji Nangka (Artocarpus Heterophyllus Lamk). 2012.

[13] L. Huang, J. Zhao, Q. Chen, and Y. Zhang, "Nondestructive measurement of total volatile basic nitrogen (TVB-N) in pork meat by integrating near infrared spectroscopy, computer vision and electronic nose techniques," Food Chem., vol. 145, pp. 228-236, 2014.

[14] I. Widyastuti and S. Putro, "Analisis Mutu Ikan Tuna Selama Lepas Tangkap," Maspari J., vol. 01, pp. 22-29, 2010.

[15] A. Subagio, W. S. Windrati, and Y. Witono, "Pengaruh penambahan isolat protein koro pedang (Canavalia ensiformis L.) terhadap karakteristik cake," J. Teknol. dan Ind. Pangan, vol. XIV, no. 2, pp. 136-143, 2003.

[16] Badan Standardisasi Nasional, "SNI 2696:2013 Fillet ikan beku," 2013.

[17] F. A. Khalafalla, F. H. M. Ali, and A. H. A. Hassan, "Quality improvement and shelf-life extension of refrigerated Nile tilapia (Oreochromis niloticus) fillets using natural herbs," Beni-Suef Univ. J. Basic Appl. Sci., pp. 1-8, 2015.

[18] Badan Standarisasi Nasional, "SNI 01-279.12006 Ikan segar - Bagian 1: Spesifikasi," 2006.

[19] I. Wibowo, Y. Darmanto, and A. Dwi, "Pengaruh cara kematian dan tahapan penurunan kesegaran ikan terhadap kualitas pasta ikan nila (Oreochromis niloticus)," J. Pengolah. dan Bioteknol. Has. Perikan., vol. 3, no. 3, pp. 95103, 2014. 